\title{
Fighting company spin
}

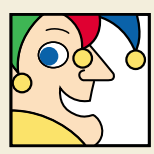

Tom Jacobs of Motley Fool (http://www.fool. com/) provides his angle on biotechnology investments. Read on and become "Foolishly" informed" He can be contacted about biotechnology and investing at TomJ@Fool.com. Jacobs cannot give individual investment advice but welcomes any. He owns shares of Harvard Biosciences.

We all want to believe the best about companies when we invest and become part owners, but corporate governance scandals from recent years warn us to be wary. Companies deploy $\mathrm{PR}$ as potent as political spin because the stakes are at least as high. This is especially true for newer biotechnology companies who must put the best possible light on everything as they struggle to survive for the long term.

Investors can easily arm themselves in this risky arena. Here are a few indicators that can signal whether your company uses or abuses the most important press releases: the ones that appear at quarterly or annual earnings time.

\section{Go team!}

Companies disseminate press releases most commonly online through BusinessWire (http://www.businesswire.com/) or PR Newswire (http://www.prnewswire.com/). Many investors read them and the news organization rewrites because they are automatically linked to their stocks through online portfolio managers such as Yahoo! Finance (http://finance.yahoo.com/) or fool.com.

Treat all press releases-earnings or otherwise-critically. They are parables told to boost the stock price. Because most company management believes that writers and analysts exist solely to lead the company pep rally, the releases are most often tailored to manipulate harried writers under impossible deadlines and editors who don't understand business. If their goal were

${ }^{*}$ Nature Biotechnology does not guarantee the veracity, reliability, or completeness of any information provided on this page; it is not responsible for any errors or omissions or for any results obtained from the use of such information; it will not be liable for any loss, damage, or investment decision arising from a reader's reliance on the information provided. really to inform, earnings releases would say, "DNA Corp. today announced that it filed its quarterly or annual report with the Securities \& Exchange Commission (SEC). You can find it through the EDGAR database provided free by the SEC at its website, http://www.sec.gov/. Have a nice day!"

\section{Shades of gray}

The two major sins in the earnings release are shading the news and hiding the numbers. Releases shade when they begin with a headline trumpeting record sales or profits, followed by a few bold bullet points below the headline. These are the items more likely to enter a deadline-crazed writer's story than any fine print. Anything less than

\section{Treat all press releases- earnings or otherwise- critically. They are parables told to boost the stock price.}

happy news is given short shrift (if 'shriven' at all). Some financial writers like to say that if the word 'challenging' appears, run. I actually like bit of candor in company releases that are invariably designed to sell ice to Eskimos.

Beware the company that quarter after quarter reports pro forma profits/losses, which are earnings defined however the company wants. They look better than earnings computed under generally accepted accounting principles (GAAP), that appear afterwards, or the company wouldn't need to produce them.

The best defense is to read the press release in conjunction with the subsequent quarterly or annual report filed with the SEC. It's a great way to learn what, if anything, management is trying to cover up.

\section{The financial statement trinity}

Hiding the numbers is a sin usually of omission. There are three major financial statements for investors: the balance sheet (cash and debt), income statement (earnings figured as if for the company's tax return), and cash flow statement (checking account). You want your company to release all three in the press release, yet most companies (let alone biotechnology companies) only release the first two and not the last.
There is no practical reason that the CFO can't produce a cash flow statement at the same time as the others. Investors rightly ask why any company would deny this information to the public until the later and oft-ignored SEC filings? Why do anything other than full disclosure? I searched dozens of public biotechnology companies' most recent earnings releases and could not find one that included a cash flow statement (if someone does find one, please forward information to me; tomj@fool.com).

\section{Danger!}

Of course it's much worse when a company releases only the income statement. Hiding cash flow is one thing, but withholding a company's cash balances and debt is a very red flag. When Enron (Houston, TX) secreted both its balance sheet and cash flow statement in the summer of 2001, that tipped a very few alert analysts to problems.

In the pharmaceutical world, ScheringPlough (Kenilworth, NJ; NYSE:SGP) included no balance sheet or cash flow statement in its Q4 and full-year 2002 earnings release. That's just one of many warnings coming from this once-proud company, partner in many alliances with biotechnology companies.

Not quite as bad, but still questionable, is the practice of releasing only part of the balance sheet data, an approach adopted by Genentech (S. San Francisco, CA; Nasdaq:DNA) and Gilead Sciences (Foster City, CA; Nasdaq:GILD) in January, and Harvard Biosciences (Holliston, MA; Nasdaq:HBIO) in March. These folks are the ones I could find; there are certainly others. Why not tell all? Is there a shortage of fonts?

\section{Best practices}

What investors want is a company that always provides the most information possible in the clearest manner. The best company earnings press release says something like, "DNA Corp. Reports Third Quarter Results," states any problems upfront, or only at the end happens to mention record revenues, earnings, and cash flow. The release solely discusses business featuresproducts on the market and in development, sales, and so on-and skips any earnings guidance.

With 9,000 public companies to choose from, including at least 460 that arguably toil in the biotechnology and drugs realm, there's no reason to accept second best. Just the facts, Ma'am? It does happen.

Until next month, stay Foolish! 